\title{
"MONOLINGUAL OR BILINGUAL APPPROACH?" THE BEST APPROACH TO TEACH SPEAKING FOR BEGINNER LEVEL
}

\author{
Yuliyanto Sabat \\ STKIP PGRI Sidoarjo \\ sabatkeren@gmail.com \\ Aulia Kususma Wardhani \\ STKIP PGRI Sidoarjo \\ au_wardhani@yahoo.com
}

\begin{abstract}
Some English teachers argue that the use of monolingual approach or "English Only" gives a lot of exposures to students and some others report it just makes the students reluctant to speak as they understand nothing about the topics being discussed. Considering the important roles of teaching approaches on students' success to use English, it is very crucial to conduct a research on this topic. This article is an attempt to report which approach students like the most either "English Only" or bilingual approach in learning speaking. Besides, it also reveals the reasons why the students choose one of the teaching approaches. As the researcher teaches speaking for beginner level, he uses his students as the subject to facilitate him to collect the data. He uses qualitative research method by using interview, questionnaire, and classroom observation to collect the data. The result of this research showed that students' negative perception on the use of English only and positive perception on the use of code switching supported by the result of questionnaire $95.65 \%$ participants chose strongly agree for code switching as their preferable teaching approach with the most common reasons on the material comprehension (86.86\% strongly agree) and building self- confidence (78.26\% strongly agree).
\end{abstract}

Keywords: monolingual approach, bilingual approach, classroom interaction

\section{INTRODUCTION}

The needs of English as a means of communication are very essential for some reasons. The first is for one's brighter career. According to Rivers the objectives of learning spoken language are related to the need in the contemporary world for oral communication and to the career plans of the students (1983:38). People who can speak English well may have a greater chance of further education, or finding employment and gaining promotion. More and more educators, governments, ministries of education and employers need people who can speak English well. Companies and organizations want staff who can speak English in order to communicate within the international marketplace. In addition, the beginning of Asian economy society forces people to compete with other 
countries using English as a global lingua franca. It is a contact language "between persons who share neither a common native tongue nor a common (national) culture, and for whom English is the chosen foreign language of communication" (Firth in McKay and Rubdy, 2009: 15). The other reason of mastering speaking skill is to access up to date information in fields including science, technology and health. Good English speakers will be in a strong position to help their country's economic, social and political development. So, by learning to speak English well, students gain a valuable skill which can be useful in their lives and contribute to their community and country (Baker and Westrub, 135:2003).

There are two types of spoken language in oral communication, transactional and interpersonal. Gebhard (1996:169) describes that in transactional language related to speaking; the focus is on the meaning of the message. While Brown (2001:273) describes that aim of transactional language is to carry out the purpose of conveying or exchanging specific information. In other words students only interact with others in the extent of question and answer activity and the purpose of interpersonal according to Gebhard (1996 169) the focus is on the maintaining social relation. Brown (2001:273) also describes that the aim of interpersonal language is to carry out more for the purpose of maintaining social relationship that for the transmission of facts and information. In other words, students have to develop their interaction with other in the extent of social relationship. In the process of teaching learning, English teachers may not teach only one type of oral communication either transactional or interpersonal. Both types of oral communication should be taught to the students although they are still in the beginner level. By doing so, students, particularly those who are at the beginner level, will be able to convey both exchanging specific information and maintaining the social relationship for transmission of facts and information.

Teaching speaking to the students at the beginner level is not that easy. English teachers need to know who they are and what characteristics they possess so that the teaching goals can be achieved. The students at the beginner level have their own characteristics. According to Boyle (2014) there are several characteristics that beginner level students possess. First, in general, in the process of conveying their ideas, these students usually use basic words, phrases and expressions. The second one, students at this level memorize simple phrases and sentences in the process of learning. Third, they rely on non-verbal communication. Fourth, they understand phrases and short sentences; they begin to follow instructions and class discussion. Fifth, if they are reading a certain text, they will be able to understand the reading texts with support (jboyle@benchmarkeducation.com). In addition, Horwitz (2009) explained that there are three characteristics of learners at beginner level. The first is motivation. It involves both the reasons that the learners have for learning a language as well as the intensity of their feeling. For instance, some learners only study the language because of language requirements, while others expect to use the language in their future career. Those who hope to use the language for career purposes probably have a stronger motivation than those people who simply hope to pass a language requirement. Another is anxiety. It includes uncomfortable feelings when learning or using the new language. The other is learners' beliefs. Beliefs about language learning are important because they influence how 
students approach language learning strategies that they choose to use. Many language learners, for example, think that they are too old to learn a foreign language well. In fact, while learning speaking, students at the beginner level tend to encounter several barriers.

According to Baker and Westrub (144:2003), there are several hindrances for in learning speaking. The first hindrance is dealing with cultural differences. The social roles and rules for speaking can be different in each culture. These social rules have a strong effect on a learner's interest and ability to learn to speak in a foreign or second language. For example, in some cultures, students are not expected to speak until they are asked to do so by the teacher. This makes it more difficult for students to practice conversation. The second one is personal differences. The ability to learn a new language and succeed in language learning depends on what type of learner we are. Some people are naturally happy to try anything new and are not afraid to make mistakes, while others are afraid of new situations. The third is dealing with lack of confidence. Their request or question may be misunderstood. This may result in a friendly joke but it could also end in a situation where students become embarrassed and are not sure how to continue. Then, they suddenly lose their confidence. The forth is dealing with a big challenge. When students start learning a new language, they may probably find that there is too much to remember and too much to understand. It can seem like a big challenge to reach the stage at which communication becomes easier and more useful. The fifth is dealing preparation for speaking. Many students find it difficult to respond if the teacher asks them to say something in a foreign language. They may have little idea about what to say, they may not know the words to use, or they may not be sure how to use the grammar. Last but not least is dealing with the interest of the topics. Students find it difficult to have a conversation on a topic that they know little about.

By knowing the barriers which will be encountered by students to learn speaking, English teachers should be very carefully to choose a certain teaching approach for teaching speaking. It is a fact that teachers' teaching approach will give a great impact on the students' success in learning a certain subject, including speaking. There are at least two approaches for English teachers in teaching and learning process particularly in speaking class, namely monolingual approach or "English only" and code switching.

In speaking class, some teachers believe that teaching English should use monolingual approach in which teachers should explain, instruct, and comment the students in English. In other words, they implement "English Only" in their classroom and no other languages but English. The teachers who have relied on the principle of "English Only" in the classroom setting vehemently denying and disallowing the use of the English learners' first language (L1) for any purposes (Keller,2016:2). They even make classroom rules for the students who speak other languages of English will receive a certain punishment which have been agreed by both teachers and students. They followed what Krashen (1985) stated "The students' L1 should not be used in the classroom so as to maximize the exposure of the target language". Some studies have shown that monolingual "English Only" approach has by no means always been the norm in the teaching of English to speakers of other languages, with regard to both overseas teaching of English as a foreign language as well as the teaching of English as a second language as 
practiced within the United States (Baron, 1990; Crawford, 1991). Keller in his research also showed that in 2010 the American Council on the Teaching of Foreign Languages (ACTFL) recommended that language educators and their students use the target language as exclusively as possible (90\% plus) at all levels of instruction during instructional time and, when feasible, beyond the classroom (2016:15). Strengthening Keller, Vivian Cook (2001) outlined the predominant "monolingual principle" of 20th century L2 instruction, namely the "L2 Only" classroom, and countered that the prevailing motivations offered in support of a virtual L2 environment still did not preclude a role for the L1 in the classroom (Cook, 2001, p. 404; Macaro, 2001).

In addition, Elis (2015) stated "It remains indisputable that the more students can receive and incorporate L2 exposure, the faster the students may learn the L2". Another argument on the use of monolingual approach is that if the teacher explains English by combining students' L1 and the target language (code switching), it can distract students' complete comprehension on the information delivered in target language. In other words code switching potentially hinders L2 acquisition so that the goal of teaching learning process will not be reached. To strengthen this statement, a study by Tsukamoto (2012) in Japan found that students had a negative perception of teachers' code switching with the potential to hinder L2 acquisition. Code switching by the teacher affected the students' perceived fluency of lecture and broke the momentum which was required for more complete L2 understanding on the part of the students. The other argument on the use of monolingual approach is an effort of maximizing English exposure in teaching learning process. In this case Krashen (1985) had insisted that the students' L1 should not be used in the classroom so as to maximize the exposure of the target language.

While on the other situations, some English teachers disagree with the use of monolingual approach. They prefer using the combination between students' L1 and the target language in teaching English which is called as code switching in which the teacher uses systematic alternating use of two languages or language varieties within a single conversation or utterance (Lightbown, 2001:598). These teachers believe that with the continued expansion of English use as a foreign or second language, code switching has become an ever-increasing norm within English language societies and throughout the increasingly globalized world of speakers using English as part of a multiple language repertoire (Greggio\& Gil, 2007). In addition, L1 code switching allows learners to retain focus on the broader goals of a learning task while concomitantly working out ways to address a specific learning issue. In a relaxed, yet fully focused manner, learners may more readily participate in classroom practice and activities with greater resultant advancement in learning the English language (Modupeola, 2013).

Besides, through code switching, learners require the ability to draw from a range of relevant languages, including but not limited to English, as support for the learner's communicative purposes. In further detail arguments they stated code switching is a normal practice among bilingual and multilingual speakers in relation to situational factors, such as setting and social relations, as well as speaker motivations (Wolfram \& Schilling, 2015). Research indicates that benefits attributable to proper employment of L1 code switching with EFL learners include a head start of successful learning achievement so as to encourage 
the gradual yet continuous increase in English proficiency, strategy development with the student in order to make difficult learning tasks more practicably manageable, and thus attainment and maintenance of student interest in further language learning tasks (Storch \& Wigglesworth, 2003; Swain \& Lapkin, 2000; Anton and DiCamilla, 1998). Supporting the previous statements Jacobson had recognized in the broadest of terms in 1976, code switching provided individual bilingual speakers with the potential to cope with the whole universe of experience through the two language media: "Therefore, it is no small wonder that they not only switch from one language to another as they move between situations but at times they also do so within the same situation and even within the same sentence" (p. 3).

Both "English Only" and code switching have strengths and weaknesses. The following is a table showing the benefit and disadvantages of both approaches.

Table 1: Benefits and disadvantages

\begin{tabular}{|c|c|c|c|}
\hline No & Types of Approach & Benefits & Disadvantages \\
\hline 1 & $\begin{array}{ll}\text { Monolingual } & \text { Approach } \\
\text { (English Only) } & \end{array}$ & $\begin{array}{l}\text { - Maximizing the } \\
\text { exposures of the } \\
\text { target language. } \\
\text { - The more } \\
\text { students receive } \\
\text { L2, the faster } \\
\text { they learn it. }\end{array}$ & $\begin{array}{l}\text { - The students may } \\
\text { be tense in the } \\
\text { learning process } \\
\text { as they do not } \\
\text { have adequate } \\
\text { vocabulary for } \\
\text { the given topic. } \\
\text { - The students may } \\
\text { not be able to } \\
\text { draw conclusion } \\
\text { from the given } \\
\text { topics due to the } \\
\text { lack of } \\
\text { vocabulary in } \\
\text { target language. } \\
\text { - The students may } \\
\text { find it difficult to } \\
\text { answer the task as } \\
\text { they do not } \\
\text { understand the } \\
\text { topics discussed. } \\
\text { - It potentially } \\
\text { reduces the } \\
\text { students interest } \\
\text { in learning target } \\
\text { language }\end{array}$ \\
\hline 2 & $\begin{array}{l}\text { Bilingual Approach (Code } \\
\text { switching) }\end{array}$ & $\begin{array}{l}\text { Allowing } \\
\text { learners to retain } \\
\text { focus on the } \\
\text { broader goals of } \\
\text { a learning task } \\
\text { while }\end{array}$ & $\begin{array}{l}\text { - It can distract } \\
\text { students' } \\
\text { complete } \\
\text { comprehension } \\
\text { on the } \\
\text { information }\end{array}$ \\
\hline
\end{tabular}




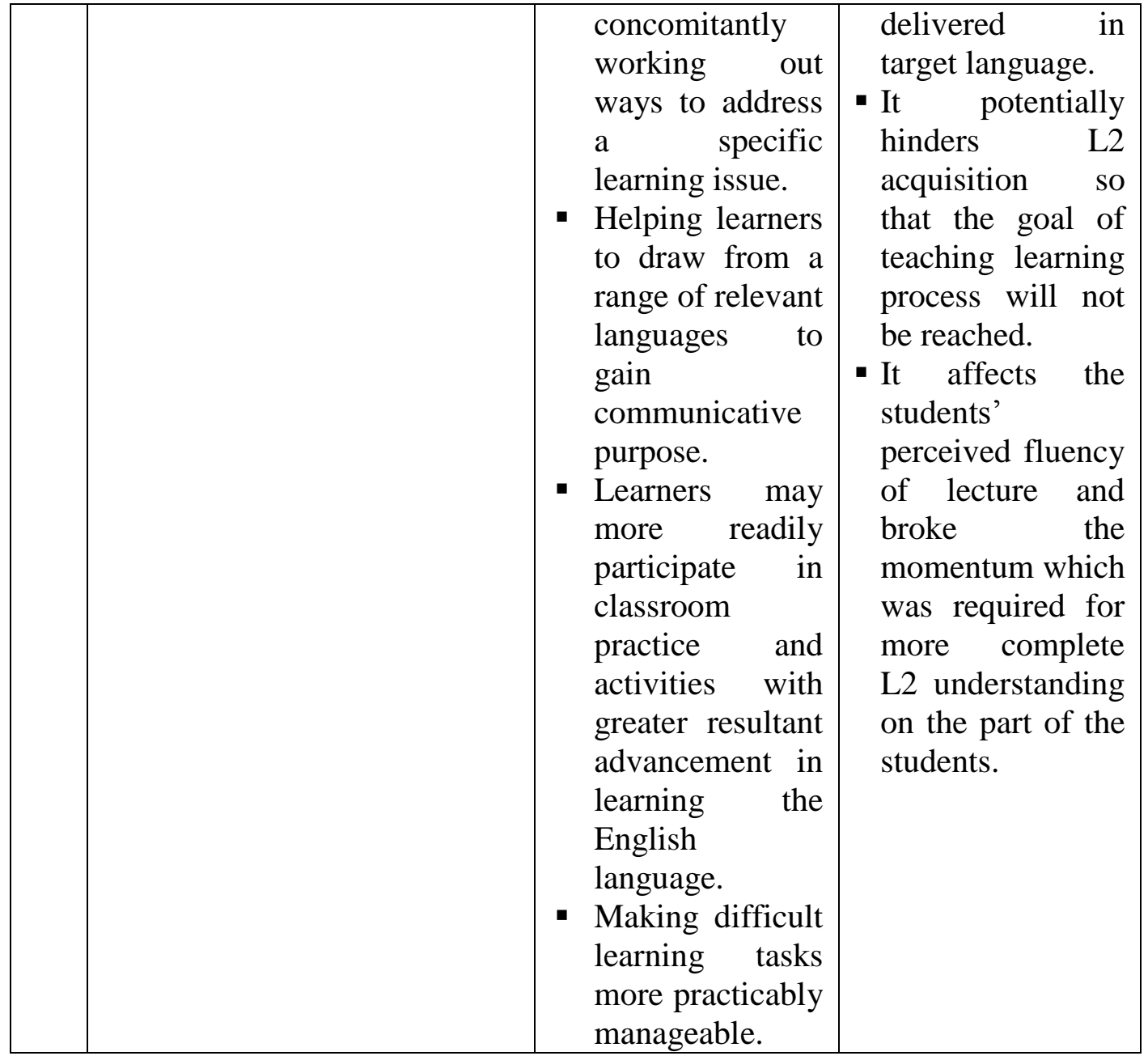

Helping students to cope with their learning problems is teachers' main duty. Once they choose the inappropriate teaching approach, students' learning achievement will be on the risk. We teachers absolutely want our students to be successful to use their English as what we have set out the goals in the lesson plan. Students' success is the teachers' pride and no other things. On the contrary, students' failure will be teachers' burden and this is our challenge to help the students to get rid of the learning failure. Thus, the research on teachers' teaching approach should be conducted because the success or the failure of our students depends on us teachers. Based on the illustration mentioned above, the researcher decided to conduct a research with the research title "Monolingual or Bilingual Approach?" the Best Approach to Teach Speaking for Beginner Level.

\section{METHOD}

In this research, the researcher would reexamine which of the best approach could be used for teaching approach based on the students' preference. He would analyze and describe all the data in form of words and sentences. Therefore, he chose qualitative as his research method. According to Creswell (2012:16) one of the characteristics of qualitative research is analyzing the data for description and themes using text analysis and interpreting the larger meaning of the findings. In more detail, this research belongs to case study as the 
researcher wanted to describe the best teaching approach in the classroom where he taught. Yin in McMillan (2008:288) described that case study research as a flexible form of inquiry best suited for studying a particular phenomenon within its natural context. The participants of the research were the students in the first semester taking speaking for beginner level course. One of the considerations of choosing these students as the research participants was to facilitate the data research collection as he was the one teaching speaking subject in this class. In addition, to collect and analyze the data, the researcher followed some procedures as his research design. This research design is suggested by Arikunto (2010:13). The following is the research design.

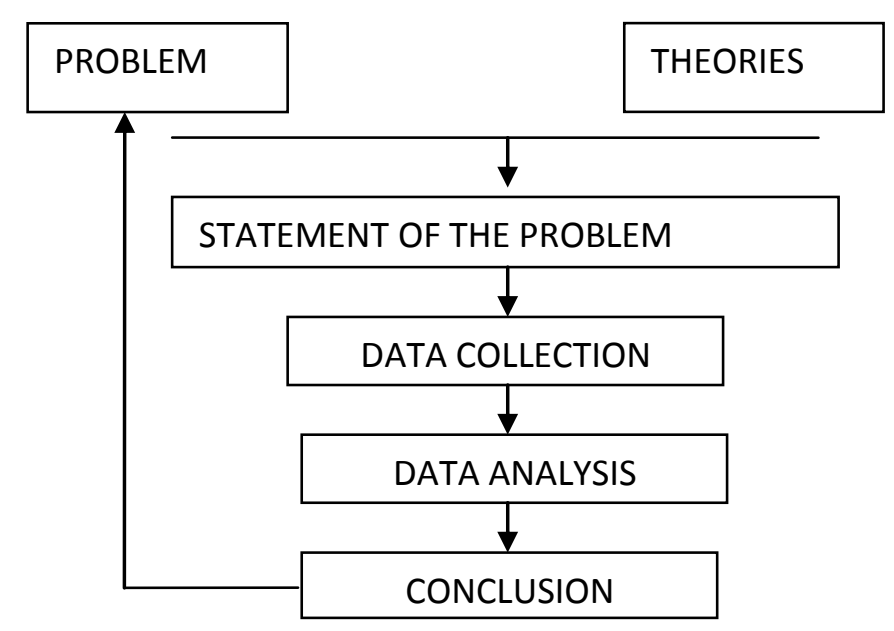

Figure 1:A suggested Research design by Arikunto

The problem which appears and needs to be solved in this research is English teachers should not let the students' success of learning speaking on the risk. Therefore, they should decide the best approach of teaching speaking for beginner level. It is a fact that teachers' teaching approach will give a great impact on the students' success in learning a certain subject, including speaking. There are at least two approaches for English teachers in teaching and learning process particularly in speaking class, namely monolingual approach or "English only" and code switching.

\section{Statements of the problems}

From the background explained in the previous paragraph, the researcher formulates the statement of the problems. The formulated statements of the problem are:

1. How is the perception of students on the approaches used by the teacher in teaching speaking for beginner level?

2. What approach do students prefer in learning speaking for beginner level?

From those two statements of the problem, the objectives of the research are to describe the students' perception on a certain approach used by the teacher 
in teaching speaking for beginner level and to describe the approach students prefer in learning speaking for beginner level.

\section{Research Data}

The data of the research were in form of the result of participants' responses from questionnaire and the result of interview to describe the students' perception toward the chosen approach in learning speaking. To collect the data, the researcher used several research instruments. They were interview, questionnaire, and classroom observation. When interviewing the research participants, the researcher did not make any listing questions. He just did it immediately and no predetermination of question topics or wording. Therefore, he decided to choose informal conversational interview as his type of interview. According to Cohen (2000:270) One of the characteristics of informal conversational interview is questions emerge from the immediate context and are asked in the natural course of things; there is no predetermination of question topics and wording. In addition, the researcher also used questionnaire as his instrument. It consisted of several questions in written form (Hamalik, 2007:108) related to the students' preference on teacher's teaching approach. In the questionnaire each participant is asked to choose one answer based on Tri Regression Measurement, which contains five levels; strongly agree-agree-uncertain or unsure-disagree-strongly disagree (Hago\& Khan, 2015: 91). The following is the questionnaire used in the research.

\section{Questionnaire}

Instructions:

1. Read the statements provided in the column below.

2. Decide your choice on by giving a check list on the provided column.
SA : Strongly Agree
DA : Disagree
AG : Agree
SD : Strongly Disagree
UC : Uncertain

\begin{tabular}{|l|l|l|l|l|l|l|}
\hline No & \multicolumn{1}{|c|}{ STATEMENT } & SA & AG & UC & DA & SD \\
\hline 1 & $\begin{array}{l}\text { I like having a lecturer explaining the } \\
\text { material through code switching } \\
\text { approach. }\end{array}$ & & & & & \\
\hline 2 & $\begin{array}{l}\text { When using code switching, i can } \\
\text { understand more on the material. }\end{array}$ & & & & & \\
\hline 3 & $\begin{array}{l}\text { I can build my confidence to use English } \\
\text { when my lecturer uses a code switching } \\
\text { technique. }\end{array}$ & & & & & \\
\hline
\end{tabular}

The researcher also used classroom observation to collect the data. Classroom observation is a 'pivotal activity,' which played crucial role in classroom research (Hopkins, 1996). This instrument was used to observe and write the students' reaction while the technique was being implemented. It is used to write whether or not the passive students who seemed to ignore the subject 
changed to be more active and braver to express their ideas in a discussion. After all, the data were analyzed.

\section{Data Analysis}

The data were analyzed using the following from four related steps.

1. Preparing the data.

In this stage, the researcher checked the data resulted from the instruments. The main purpose of the preparation stage is in order that data obtained are easily processed and analyzed.

2. Data analysis

The data obtained through interview and observations were analyzed by using descriptive qualitative manner. The data from interview will be used to answer the first statement of the problem that is "How is the perception of students on the approaches used by the teacher in teaching speaking for beginner level?". The researcher recorded all information dealing with the given questions from research participant. Then, he transcribed the result of interview from participant to make sure that all data would be well analyzed and there would be nothing missing. The analyzed data from interview would be supported by the result of classroom observation in order to really describe the real situation existing in teaching and learning process, particularly on the participants' perception during being taught using a certain type of approach by the English teacher.

The data which had been collected from questionnaire were analyzed to answer the second statement of the problem that is "What approach do students prefer in learning speaking for beginner level?". After collecting the participants' response through questionnaire, the researcher calculated each choice based on Tri Regression Measurement, which contains five levels; strongly agree-agreeuncertain or unsure-disagree-strongly disagree. Then, he presented the result of participants' responses in form of diagram.

3. After analyzing the data, the researcher described the data by classifying into parts based on the problems of the study. In this step, the researchers focused on the formulated statements of the problem to get rid of the research threat.

4. The researcher drew conclusion.

The conclusions were drawn after knowing the result and discussion of the research. In this part, the researchers were also gave recommendation as the follow up of the findings.

\section{RESULTS AND DISCUSSION}

To describe the students' perceptions, the researcher interviewed the students. The result of interview revealed that most of the students felt anxious when the lecturer asked question in English. They expressed their thought with different expressions but the point refers to anxiety. Some students said with the combination of L1 and the target language "nervous, pak" (I am nervous, sir) but many used Indonesian expressions such as "keringat dingin, pak" (They felt very nervous). Since the researcher used Bahasa Indonesia, the students were free to answer either in Bahasa or English. They answered without any pressure. When the students felt nervous, they may experience one of barriers as what Baker and Westrub (144:2003) called "Preparation for speaking". Many students find it 
difficult to respond if the teacher asks them to say something in a foreign language. They may have little idea about what to say, they may not know the words to use, or they may not be sure how to use the grammar. Some others answered "Biasa-biasa saja, tapi bingung" (It is just so so but I am actually confused). They do not understand completely on the materials explained by the lecturer if conveyed in English. They confessed that because of lack of vocabulary they cannot comprehend the materials taught by the lecturer. Therefore, the teacher should use code switching to repeat the instruction so that they can understand what the teacher is asking as it is stated by Greggio and Gil, 2007; Cipriani, 2001 that code switching should be used by the teacher as a repetitive function wherein the L1 is used as a resource for L2 learning including the facilitation of task management.

It was also found out that the students actually wanted to say that they enjoy listening while the lecturer is explaining in English but vocabulary hinders them to catch up what the lecturer means if all the sentences are expressed in English fully. To accommodate what the students' wishes and to achieve the learning goals, Eldridge (1996:306) stressed the use of code switching in this the situation in which "messages are reinforced, emphasized, or clarified where the message has already been transmitted in one code, but not understood". Strengthening this fact, some researches indicate that benefits attributable to proper employment of L1 code switching with EFL learners include a head start of successful learning achievement so as to encourage the gradual yet continuous increase in English proficiency, strategy development with the student in order to make difficult learning tasks more practicably manageable, and thus attainment and maintenance of student interest in further language learning tasks (Storch\& Wigglesworth, 2003; Swain \&Lapkin, 2000; Anton \& DiCamilla, 1998). The following pictures showed the situation in teaching and learning process.

Picture 1: The atmosphere of teaching learning process (Preparing and delivering arguments)
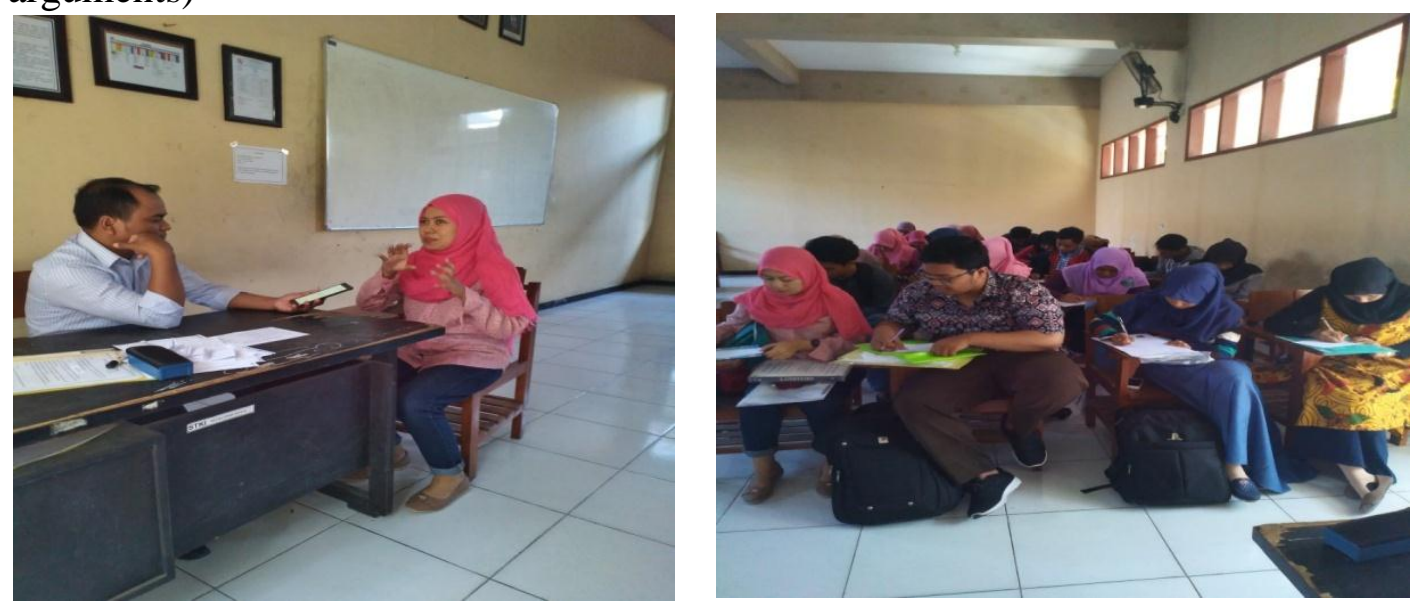
Picture 2: The process of Interview

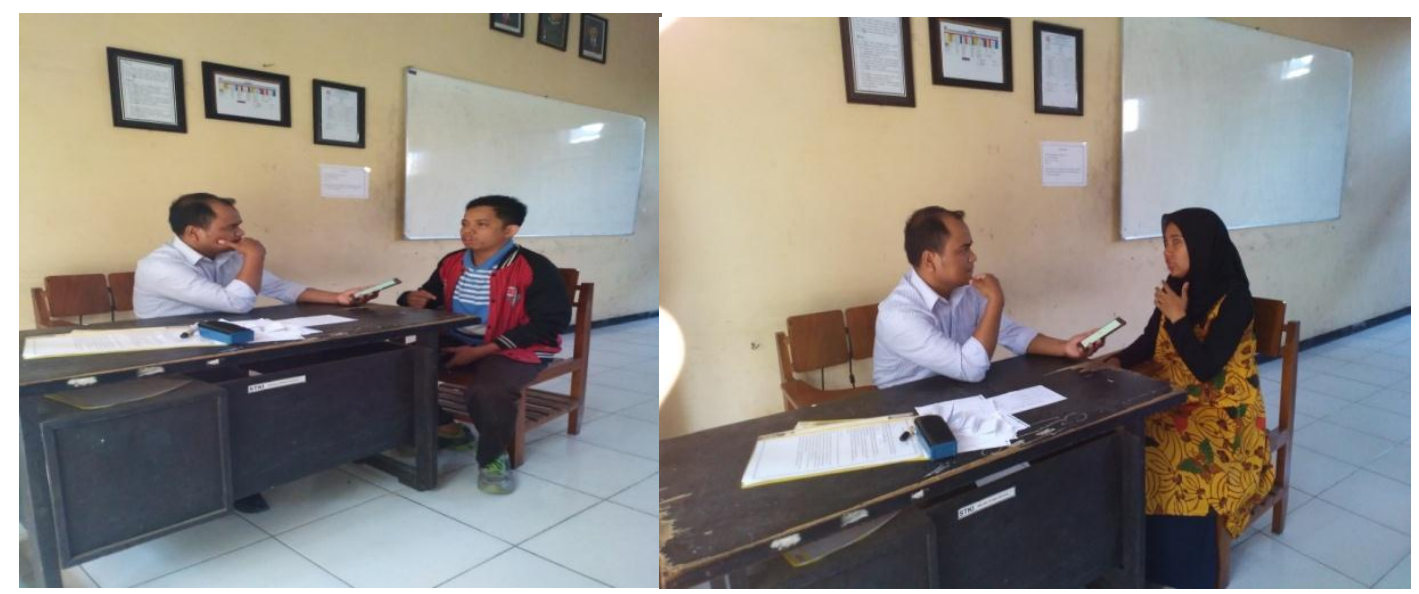

In addition, the students actually wanted to say that they enjoy listening while the lecturer is explaining in English but vocabulary hinders them to catch up what the lecturer means. It implicitly answers the questions on "What is the best approach to teach speaking for beginner level?" We can actually accommodate what their wishes without making them frustrated. "English Only" is not appropriate in this classroom as many students do not understand the materials due to lack of vocabulary. This is the biggest obstacle for them. In this situation, lecturers should explain the materials by combining the target language and students' L1 (Code switching) as repetition strategy to give students' complete comprehension on lecturer's explanation. In line with this statement, Baker (2001) also suggested that "Teachers in the classroom explain a concept in one language, and then explain it again in another language, believing that repetition (in both languages) adds reinforcement and completeness of understanding" (Baker, 2001: 5 , as cited in Wang, 2006).

If students understand the materials, they will feel enjoyable without feeling intimidated in learning English. Then they will have a comfortable learning environment. It is very necessary for students to have a comfortable learning atmosphere as once students are comfortable with the environment, without any unnecessary anxiety due to initial emotional support, learners will be able to more readily and fully focus and participate in classroom practice and activities with greater success in a more relaxed and comfortable manner learning the English language (Modupeola, 2013). The result of interview on the students' preference of teaching approach is also supported by the result of questionnaire. Based on the result of distributed questionnaire, it was found out that $95.65 \%$ participants chose code switching as their preferable teaching approach; twenty (23) participants chose "strongly agree" and (1) participants chose "uncertain". The chart is shown as below. 
Chart 1: Result of questionnaire

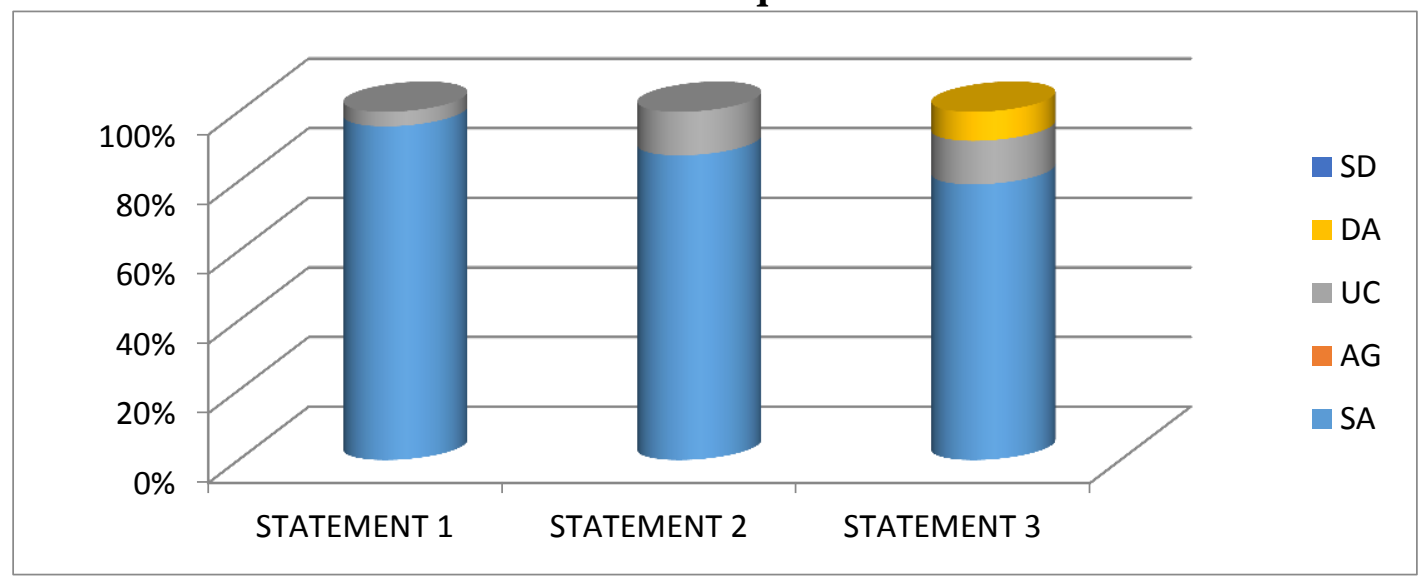

Notes:

$\begin{array}{llll}\text { SA } & \text { : Strongly Agree } & \text { DA } & : \text { Disagree } \\ \text { AG } & : \text { Agree } & \text { SD } & : \text { Strongly Disagree } \\ \text { UC } & : \text { Uncertain } & & \end{array}$

STATEMENT 1: I like having a lecturer explaining the material through code switching approach.

STATEMENT 2: When using code switching, I can understand more on the material.

STATEMENT 3: I can build my confidence to use English when my lecturer uses a code switching technique.

There are some responses given by students why they chose code switching as their favorite teaching approach instead of English Only. The first and the most common response are on the students' comprehension. The result of questionnaire revealed $86.86 \%$ participants chose "strongly agree" on the statement "When the lecturers use code switching approach, the students can understand more on the materials"; twenty one (21) participants chose strongly agree and three (3) participants chose "uncertain". It is strengthened by the result of interview; the students argue that if the lecturer uses English only, they will not understand the materials completely. In addition, teachers who have relied on the principle of English Only in the classroom setting vehemently denying and disallowing the use of the English learners' first language (L1) for any purposes (Keller, 2016:2). It will make the students more stressful. In the interview, it was also found out one of the most surprising facts that if the students cannot answer the lecturer's questions conveyed through English Only approach, they will be demotivated and have no interest in learning English. We lecturers should avoid such condition. Avoiding this circumstance, Atkinson (1993) suggested in simplest terms: "Teachers should use English where possible and L1 where necessary" so that students will be able to answer lecturers' questions, at last they will get motivated as they are successful to use their English. Hence, their selfconfidence will be continuously built. 
Building self-confidence becomes the second response on the preference of code switching approach. $78.26 \%$ participants chose "strongly agree" on the statement "I can build my confidence to use English when lecturer uses a code switching approach; nineteen (19) participants chose strongly agree; three (3) participants chose "uncertain" and two (2) participants chose "disagree". From the interview, it was found out that students in the first semester should be allowed to use the combination between English and students' L1 inasmuch as they will be more confident if they can speak English although by using language combination. It is therefore, for beginners and low-proficiency learners, again by way of introductory example, code switching is now increasingly considered an effective strategy to learn, but for intermediate level students more target language input is required and therefore code switching is not approved or liked by lecturers and students (Ling et al., 2014; Jingxia, 2010; Yao, 2011; Horasan, 2014). As self-confidence is so much important in speaking skill, lecturer should use code switching approach instead of monolingual approach in teaching speaking for beginner level.

\section{CONCLUSION AND ACKOWLEDGEMENT Conclusion}

Realizing the importance of teaching approach on students' achievement in learning English, lecturers should wisely decide one of the most appropriate teaching approaches either Monolingual Approach (English Only) or Bilingual Approach (Code switching). Based on the data described above, it can be concluded that code switching should be used to teach students at the beginner level because they still lack of vocabulary. This hindrance makes the students finally cannot comprehend the English materials if it is conveyed through English Only. If the lecturer insists on using English Only approach, she/he should remember that because of using the wrong approach, students will get demotivated to learn English. This is one of the most dangerous impacts on the use of inappropriate approach. They will not be interested in producing many English words in the speech and they will just keep on sitting and listening without getting involved in the teaching learning of speaking. English teachers should not let this situation happen in the classroom otherwise the speaking teaching goals will not be achieved.

\section{Acknowledgement}

This research will not be able to be well accomplished without any supports from many sides. Therefore, the researcher would like to express his deepest gratitude to the chairman of STKIP PGRI Sidoarjo who has given a great chance to the researcher to conduct his research in the institution he leads. Second of all, he would also deliver his gratitude to all colleagues who have given such constructive insights for this research during scientific discussion and debate to find out the maximum result of the research. Last but not least, he would also convey his gratitude to all students who have been willing to help him in the process of data collection. 
“Monolingual or Bilingual Approach?” The Best Approach to Teach Speaking for Beginner Level

\section{REFERENCES}

Anton, M., \& DeCamilla, F. (1998). Socio-cognitive functions of L1 Collaborative interaction in the L2 Classroom. Canadian Modern language Review, 54 , 314-342.

Arikunto, S. (2010). PROSEDUR PENELITIAN SUATU PENDEKATAN PRAKTIK. Jakarta: Rineka Cipta.

Atkinson, D. (1993). Teaching Monolingual Class. London: Longman.

Baker, H. J. (2003). Essential Speaking Skills. New York: Continuum.

Baron, D. (1990). The English Only Question: An Official Language For American. New Haven, CT: Yale University.

Brown, H. Douglas. 2001. Principles of language learning and Teaching $2^{\text {nd }}$.New Jersey : Prentice Hall Regents.

Crawford, J. (1991). Bilingual Education: History, Politics, Theory, and Practice. Los Angeles: Bilingual Educational Service.

Creswell, J. W. (2012). Educational Research:Planning, Conducting, and evaluating quantitative and qualitative research. Boston: Pearson Education, Inc.

Cook, V. (2001). Using the First language in the Classroom. Canadian Language Review, 57 , 402-423.

Eldridge, J. (1996). Code-switching in a Turkish secondary school. ELT Journal, 50 (4), 303-311.

Ellis, R. (2015). Understanding second language acquisition (2nd edition). Oxford: Oxford University Press.

G.Gil, S. G. (2007). Teacher's and learner's use of code switching in the English as a foreign language classroom: A qualitative study. Linguagem \& Ensino, 10 (2) , 371-393.

Gebhard, J.G. 1996. Teaching English as a Foreign or Second Language: A Teacher Self Development and Methodology Guide. Michigan: The University of Michigan Press.

Hamalik, O. (2007). Proses Belajar Mengajar. Jakarta: Bumi Aksara.

Hopskins, D. (1996). Making Good Schools Linking School Effectiveness and School Improvement. Routledge , 3-4.

Horwitz,E.K.M. Tallon\&H.Luo. (2009).Foreign Language Anxiety. In J.C. Cassady(ed), Anxiety in School. The causes, consequences, and solutions for academic anxieties. New York: Peter Lang.

Jacobson, R. (1976). Social implication of Intra sentential code-switching. Paper Presented at the annual meeting of South Modern Language Association, Dallas Texas .

Keller, G. H. (2016). Code Switching in Teaching English to Speakers of Other languages. Master's Project, 480.

Khan, o. H. (2015). The Pronunciation Problems faced by Sauid EFL Learners at Secondary Schools. Macrothingk InstituteVol. 1, No.2, 2.

Krashen, S. (1985). The input hypothesis: Issue and Implication. AddisonWesley: Longman Ltd. 
Journal of English Teaching Adi Buana, Vol. 03 No. 02, October 2018

Lightbown, P. (2001). Input Filters in Second Language Acquisition. Amsterdam: John BEnjamins.

Louis Cohen, L. M. (2000). Research Methods in Education: 5th Edition. London: Routledge Falmer.

Madupeola, O. (2013). Code-switching as a teaching strategy: Implication for language teaching and learning in a multilingual society. IOSR Journal Of Humanities And Social Science, 92-94.

Macaro, E. (2001). Analyzing student teachers' code switching in foreign language. Modern Language Journal, 85 , 531-548.

McMillan, J. (2008). EDUCATIONAL RESEARCH: Fundamentals for the Consumer, 5th Ed. USA: Pearson Education, Inc.

N. Storch \& G. Wigglesworth. (2003). Is there a role for the use of the L1 in an L2 setting? TESOL Quartely, 37 (4), 760-770.

Rivers, F. 1983. Audiovisual Material: their nature and use. New York: Harper and Row Publishers.

Swain, M., \& Lapkin, S. (2000). Task-based second language learning: first language. Language Teaching Research , 251-274.

W. Wolfram \& N. Schilling. (2015). American English: Dialects and Variation (Language in Society) 3rd ed. Chichester, West Sussex: Wiley-Blackwell.

Wang, X. (2006). Code-switching between Mandarin and English in Englishdominant environment. ARECLS E-Journal, 3. 